\title{
The Penal Liability of the Moral Person in the Electoral Publicity Crimes in the Jordanian House of Representatives Electoral Law No. 6 of 2016
}

\author{
Wejdan S. Irtaimeh ${ }^{1}$ \\ ${ }^{1}$ Jadara University, Jordan \\ Correspondence: Wejdan S.Irtaimeh, Jadara University, Jordan, PO BOX 840225 Amman 11180, Jordan. E-mail: \\ wejdan0@yahoo.com
}

Received: December 29, 2018

Accepted: January 31, 2019

Online Published: February 2, 2019

doi:10.5539/jpl.v12n1p20

URL: https://doi.org/10.5539/jpl.v12n1p20

\begin{abstract}
This study aims to clarify the provisions of the liability of the moral person in the electoral publicity crimes in the Jordanian House of Representatives Electoral Law No. 6 of 2016, and to clarify the problems of implementing the criminal sentences issued against him. The study indicated that the Jordanian legislator did not stipulate any substantive or procedural rules concerning the penal liability of the moral person for the electoral crimes in the House of Representatives Electoral Law No. 6 of 2016 relying on the general rule stated in Article 74 of the Jordanian Penal Code No. 16 of the year 1960 and its amendments, which established the penal liability of the private moral persons and excluded the public moral persons i.e. the governmental department or official or public institution. The study concluded that the liability of the moral person in the electoral publicity crimes is subject to the general provisions included in the general section of the Penal Code and the Code of Criminal Procedure concerning the general procedural rules applicable to the natural person that are in line with the nature of the moral person, which constitutes a legislative deficiency as its adoption is not sufficient to establish of the penal liability of the moral person in the electoral publicity crimes, without creating an integral procedural system for prosecuting the moral person when he commits the electoral publicity crimes.
\end{abstract}

Keywords: electoral law, electoral publicity, Jordanian house of representatives, moral person, penal liability

\section{Introduction}

The legal personality is the power to acquire rights and to incur obligations. The general rule is that the legal personality is only acquired by humans, i.e. the natural person, as he is a distinct social organism, which the laws are made to regulate his affairs. However, the practical necessities and the development of social and economic life resulted in granting the legal personality to non-humans, which is known as moral personality, whether it was a group of persons or a group of funds. A moral person means: "A group of funds or persons that the law gives it the legal personality, which enables them to acquire rights and to incur obligations"1. It is agreed that the civil liability of the public or private moral person arises when its legal conditions are met, but the penal liability of the moral person was a controversial issue for the jurisprudence. Despite the importance of the moral person due to carrying out the heavy burdens that a natural person cannot perform, he may be a source of crime, a deviation or a danger that threats the society and its safety ${ }^{2}$.

The election is closely related to democracy. It is an essential component of the democratic system. It is the mean through which the power can be delegated. Due to the importance and the gravity of the electoral crimes, the Jordanian legislator, in the Jordanian Constitution of 1952 and its amendments, stipulated the guarantees and conditions of the electoral process. Article 67 of the Jordanian Constitution stipulates that: "The House of Representatives shall be composed of elected members that are elected by universal, direct and secret suffrage in accordance with an electoral law, which guarantees the following principles: a) The right of the candidates to observe the electoral activities; b) Punishment for those who tamper with the will of the voters; c) The integrity of the electoral process at all stages".

\footnotetext{
${ }^{1}$ Kamel, Sherif Sayed, (1997), The Penal Liability of the Moral Persons Comparative Study - First Edition, Dar Al-Nahda al-Arabiya, p. 3.

${ }^{2}$ Saleh, Ibrahim Ali, (1980), Criminal liability of the Moral Persons, Cairo, Dar Al Ma'arif, p.55
} 
The electoral publicity crimes are electoral crimes that affect the integrity of the electoral process and the will of the voters. In order to ensure the integrity of the parliamentary elections, the Jordanian legislator sought to organize them in the electoral law and in the executive instructions concerning the rules of the electoral campaigning to ensure equality among all candidates and to criminalize the acts that affect the freedom of the voters. According to the law it is not disputed that the natural person is liability for the electoral publicity crimes, but the problem arises when a moral person, such as the state or political parties or the media or any other moral persons, commits the electoral publicity crimes that its damage exceeds the damage made by the human when he commits the crime.

The problem of the study is the extent to which the penal liability of the moral person can be attributed to the electoral publicity crimes in the Jordanian House of Representatives Electoral Law No. (6) Of 2016, and how to implement the sentences issued against him.

\section{The Jurisprudential Dispute over the Penal Liability of the Moral Person}

The penal liability of the moral person is: "The capacity and the suitability of the moral person to incur liability for the actions committed by his representatives or members or those working on his behalf and to be subject to the penalties and precautionary measures prescribed by law for such acts" ${ }^{\prime 3}$. The idea of the penal liability of the moral person raised a lot of controversy in jurisprudence and comparative law. A part of the traditional jurisprudence ${ }^{4}$ denied the penal liability of the moral person for what occurs by their representatives while carrying out their duties, even if it was for his own account, relying on the accountability of the natural persons who committed such crimes. Another part ${ }^{5}$, which represents the modern aspect of the criminal jurisprudence, found that it is necessary to adopt the penal liability of the moral person as he represents a "criminal truth" in many fields and commits crimes that are more serious than crimes committed by natural persons. This requires the adoption of the penal liability of the moral person. Some countries have adopted the principle of criminal liability of the moral person, as a general principle, first and foremost the Anglo-American system. While others have decided his non responsibility, unless otherwise is stipulated by an explicit provision. As for our Arab legislation, some of them have been influenced by this, while the others have been influenced by the other ${ }^{6}$. They differ in the scope of determining this liability, where some of them adopted the liability of the moral person as a general principle ${ }^{7}$ while other legislations limited it to crimes that most of which fall within the financial and economic crimes $^{8}$. The French legislator has adopted the penal liability of the private and the public moral persons, except the state, in article 12112 of the new French Penal Code ${ }^{9}$. He also excluded from the extent of this liability some of the activities that are carried out by regional groups and their assemblies such as municipalities or village councils that are the subject of the delegation of the public service ${ }^{10}$, i.e. activities in which a local person delegates other public or private moral persons to perform them.

In spite of the recent emergence of the Hashemite Kingdom of Jordan, it preceded other countries in adopting the penal liability of the moral person. The Jordanian legislator adopted the penal liability of the moral person in Article 74 of the Penal Code ${ }^{11}$. He excluded the public moral persons from this liability, namely the governmental department or the official or public institution. The Jordanian legislator defined the moral persons

\footnotetext{
${ }^{3}$ Al-Zoubi, Mkhled, 2012, The Impact of the Penal Liability of the Moral Person on the Protection of Public Money Comparative Study, PhD, Amman Arab University, p.55

${ }^{4}$ They are Professor Jarou and Professor Roux from the French jurisprudence and Dr. Mahmoud Mahmoud Mustafa, Dr. Awad Mohammed from the Egyptian jurisprudence, and to illustrate the arguments of this jurisprudential approach, (Muqbel, Ahmed Mohamed Qaed , (2005), Criminal Liability of the Moral Person, a published $\mathrm{PhD}$, issue 1, Cairo University: Egypt.), p. 33-39.

${ }^{5}$ They are George Levasseur from the French jurisprudence and Dr. Mahmoud Naguib Hosni, Dr. Abdel Wahab Homed and others from the Arab jurisprudence. Their arguments were pointed (Muqbel, op,cit , p. 40 and beyond.

${ }^{6}$ Muqbel, op,cit ,p. 31

7 The Jordanian legislator in Article 74 of the Penal Code, the Iraqi legislator in Article 80 of the Penal Code.

${ }^{8}$ Including the Egyptian Penal Code, since the general principle of the Penal Code remains that the moral person may not be held criminally liable. As an exception to the general rule, some private laws have adopted this principle in some economic crimes.

${ }^{9}$ Article 121-2 French Panel Code Act no. 2000-647.

${ }^{10}$ Al Outour, Rana Ibrahim (2006), The Penal Liability of the moral Person, Damascus University Journal of Economic and Legal Sciences, vol. 22, second issue, p. 355

${ }^{11}$ Article (74) of the Jordanian Penal Code provides that: "No one shall be sentenced to punishment unless he has committed the act consciously and willingly." 2. The moral person, except the governmental department, official or public institution, shall be criminally responsible for the actions of his boss or any member of his administration or any of its representatives or employees when such acts are committed in his name or by one of his means as a moral person. 3. The moral persons shall be sentenced only to a fine and confiscation. If the law provides for an original penalty other than the fine, the fine shall substitute it. It shall be imposed within the limits specified in Articles 22 to 24 of this Law"
} 
in Article 50 of the Civil Code - and they were referred to as juristic persons -as: "Each group of persons or funds shall have a juristic personality according to a provision in the law". According to article 51 of the same law, a juristic person shall enjoy all rights, except such rights as are inherent in the status of natural person, within the limits established by the law, thus he shall have an independent patrimony, a capacity within the limits set by its establishing document or determined by law, the right to litigation and an independent domicile. Under Article 52 of the Jordanian Civil Code, juristic persons are subject to the provisions of the laws that are related to them. The moral persons are divided into two categories: public moral persons subject to the public law, and private moral persons subject to private law such as companies and associations. The public moral persons are divided into regional moral persons, headed by the state (governorates, cities and villages) and public utility persons such as public institutions and bodies ${ }^{12}$.

\section{The Quiddity of the Electoral Publicity Crimes and the Perception of their Perpetration by the Moral Person}

Most of the electoral legislations have followed the penal laws by not defining the electoral crime, and only to mention its forms. The jurisprudence has laid down several definitions for the electoral crime, it was defined as: "Any act penalized by the law - whether positive or negative, resulting in an attack on the electoral process or a violation of its proper conduct and impartiality - that emanates from a criminal intention and the criminal law imposes a penal sanction on it" ${ }^{13}$. These legislations did not also define the electoral publicity crimes clearly, but only described the regulations and the forms of the electoral publicity. But the jurisprudence has defined it as: "A group of actions carried out by the candidate or the party in order to give a good image to the voters through the electoral programs in order to create a unified public opinion that represents a specific political direction for the party and its supporters. The party or the candidate can reach - through this opinion - to authority" ${ }^{14}$. Therefore, we define the electoral publicity crime as "any positive or negative illegal electoral activity that is committed by a natural or moral person in order to convince the voters to vote for him". According to the general rules, the liability of the natural person shall exist in all the electoral crimes, provided for in the electoral legislation, if he committed them. The legislations differed in determining the scope of crimes for which the moral person can be held liable, based on two principles: the principle of generality and the principle of particularization.

- The Principle of Generality: is based on not determining the crimes for which the moral person may be held accountable. Therefore, his penal liability exists in all crimes committed in his name and for his account by the natural persons who administer it ${ }^{15}$. There is an exception to the principle of generality, which are the crimes that its perpetration by the moral person cannot be conceived, whether as the principal offender or an accomplice, such as assault and physical contact crimes. There is another category of crimes that the moral persons are not held accountable because they have a special mode such as perjury or false oath, because they can only be committed by a natural person. In Article $74 \backslash 2$ of the Penal Code, the Jordanian legislator adopted the Principle of Generality, in which the moral person is responsible for all the crimes which he can commits, thus extending the penal liability of the moral person ${ }^{16}$.

- The Principle of Particularization: is based on determining the crimes for which the moral person can be held liable, whether those stipulated in the general penal code or in any other criminal legislation. The French legislator adopted the principle of particularization while adopting the penal liability of the moral person in article 121-2 of the new Penal Code of 1994. In 2004, the French legislator made a fundamental amendment, abandoning the principle of particularization and adopting the principle of generality, by which the moral person became criminally liable for all crimes ${ }^{17}$.

While the Jordanian legislator did not stipulate in the Jordanian House of Representatives Electoral Law No. 6 of 2016 provisions regarding the liability of the moral person for the electoral crimes, relying on the general rule stated in Article 74 of the Penal Code and did not limit it to a particular type of crime, the liability of the moral person for the electoral publicity crimes shall be subject to the general provisions of the Penal Code. The question arises: Is it possible to imagine that a private or public moral person has committed electoral publicity

\footnotetext{
${ }^{12}$ Muqbel, op,cit, P. 293.

${ }^{13}$ Al-Hadithi, Omar Fakhri Abdul Razzaq, Prevention of Electoral Crime, Research published in the Journal of the Faculty of Law, Anbar University, 2010, p.109

${ }^{14}$ EL -Wardi, Brahimi, (2008), The Legal System of Electoral Crimes, Alexandria University, Thought House, First Edition p.113 .

15 AlMuqbel, op. Cit., P.273

${ }^{16}$ ALShashani, Rashed, ( 2014 ), Criminal Liability of the moral Person in Accordance with the Jordanian Legislator's Plan, Al-Manara Journl, Volume 20 issue 2/ A, p. 198

${ }^{17}$ Al- Zoubi, op. Cit., P. 273.
} 
crimes? In order to answer this question, we will illustrate in the following the electoral publicity crimes included in the Jordanian Election Law and the Executive Regulations issued by the Independent Electoral Commission.

The electoral process begins by calling the voters to the elections and ends with the announcement of the electoral results. It begins by registering the voters in the voters' lists and ends with the announcement of election results. The electoral publicity is one of the most important stages for participating in the electoral process. It is a method of introducing the voters to the candidates and their programs, where the candidate or the party seeks to highlight its advantages through the use of various means of audio or visual advertising as well as the printed newspapers and magazines, and holding seminars, conferences and electoral festivals and to influence the voters and to urge them to vote in favor of the candidate. Therefore the States stipulate in their electoral legislation guarantees to ensure the integrity and legitimacy of electoral publicity. In the electoral law No. 6 of 2016, the Jordanian legislator provided for the principles of equality of publicity among all candidates and lists, the neutrality of public authority, and the integrity of the procedures and means used in electoral publicity. While the electoral publicity is a guaranteed right for the candidates, the use of such right may involve legal violations that affect the integrity, independence and impartiality of the electoral process and as a result affect the final results of the election. So we will deal with the most important crimes committed in the stage of electoral publicity, which are the crimes that affects the organization of electoral publicity, and the crimes that affects the means of the electoral publicity and its subject and funding.

\subsection{Crimes Related to the Organization of the Electoral Publicity}

\subsubsection{The Crime of Non-Compliance with the Places allocated for the Electoral Publicity}

Most of the electoral legislation intervened to regulate and define the places allocated for electoral publicity in order to guarantee the principle of equality, where it determined the places allocated for the placement of advertisements, leaflets and posters for the electoral publicity of the candidates, and prevented at the same time the placement of electoral publicity outside these places. Not all the places can be available for electoral publicity otherwise it would turn into chaos. Therefore, these places and spaces are distributed equally between the candidates by the competent authority on the basis of a request submitted to them. These places are allocated according to the priority of the request. Most electoral legislations agree that the practice of electoral publicity outside the allocated places is an electoral crime. But it differs in how to stipulate the provisions related to the determination of places allocated for the electoral publicity and the criminalization of acts that are committed outside these places. Some of them stipulates these provisions explicitly in its articles, meaning that the legislator is responsible for determining these places and stipulating their provisions and punishing all those who violate these provisions, while the other part of these legislations do not stipulate provisions concerning the places of electoral publicity which constitute a deviation from these provisions to the executive authority ${ }^{18}$. The Jordanian legislator dealt with the issues related to the organization of electoral publicity. He delegated the Greater Amman Municipality Council, municipal and local councils to determine the places allocated for electoral publicity. The Jordanian legislator in Article (22/2) of the Election Law of the House of Representatives prevented the candidates from using the slogan of the state in public meetings and electoral advertisement, and the use of loudspeakers on transportation. The Jordanian legislator prevented the candidates in Article (22/3) from exercising the electoral publicity by putting up any electoral advertisement or statement or placing them on the telephone and electricity poles, traffic lights and public property, including pictures, drawings and writings. This article also prohibited putting up any electoral advertisement or statement on the walls or placing any electoral advertisement or statement or installing it in a way that harms public safety. Paragraph 5 / A of the same article also prohibits the establishment of electoral festivals and gatherings within 200 meters from the polling and counting center. In paragraph (4) article (21) of the same law the legislator prohibited the exercise of the electoral publicity in ministries, governmental departments, official and public institutions, educational institutions and houses of worship. Article 23 of the law also prohibits the government employees, official and public institutions, the Mayor of Amman, members of the Amman Municipality Council, their employees, heads of provincial, municipal and local councils, their members and employees from carrying out any advertising and campaigning activity for any candidate in their place of work. The special executive regulations also confirmed this prohibition through the rules of the electoral campaigning of 2016 and in article (7) with its paragraphs (E, F, I, L, N). The moral person may commit crimes related to organization of the electoral publicity such as political parties and electoral campaigning companies. The material element of this crime is the fact that the moral person has committed, through his boss, or any member of his administration or directors or any of his representatives

${ }^{18}$ El-Asadi, Diaa Abdullah Aboud Jaber, (2009), Election Crimes, Zain Legal Library, Lebanon, First Edition, p.301 
or employees, any positive or negative action contrary to the legal rules that determine the places of election publicity. The positive act is to place advertisements, flyers or posters of electoral publicity in other than the places for which they were destined, whether made by the party or its candidates or those who work for him, or by the electoral campaigning company in agreement with the candidate or party ${ }^{19}$. In contrast to the French legislator, the Jordanian legislator did not criminalize the negative act that constitutes the material element of this crime, which is to abstain from using the place allocated for the candidate's electoral publicity or assigning it to others because it violates the principle of equality between candidates ${ }^{20}$. As for the moral element of this crime, it requires the existence of the general intention that requires knowledge and will, that is to say, that the moral person, the political party, the electoral campaigning company or other moral persons knows the elements of the criminal behavior. Nevertheless, his intention tends to carry out the act. The Jordanian legislator punished this crime in article (56) of the Electoral Law by imprisonment for a period not less than three months and not more than one year, or a fine not less than two hundred dinar and not more than five hundred dinar or by both penalties.

\subsubsection{The Crime of Electoral Publicity outside Its Time Frame}

The Jordanian legislator determined the time frame in which the candidates who run for a membership in the House of Representatives are entitled to exercise the electoral publicity in Article 21 of the Jordanian House of Representatives Electoral Law No. 6 of 2016. It starts from the date of the candidature and ends twenty-four hours before the day of the election. Therefore, carrying out the activities of the electoral publicity before or after the legally determined periods, such as putting up electoral advertisements, holding electoral conferences or seminars, or a candidate promoting his election program outside these specified periods, is considered an electoral crime under the electoral law. The material element of this crime is that the moral person, such as the political party or the electoral campaigning company or the media, has carried out any of the acts of the electoral publicity and in any way or means, outside the period specified for the electoral publicity such as publishing, distributing or putting up banners or electoral advertisements, holding speech festivals or carrying out electoral publicity by radio or television or via social media and electronic sites. The moral element of this crime is realized by the existence of the general criminal intent, which is the knowledge of the period specified for the electoral publicity ${ }^{21}$. The Jordanian legislator did not provide for a special text stating the penalty of the author of the electoral publicity crime that is committed outside its time frame $\mathrm{e}^{22}$ and we wish that the Jordanian legislator will explicitly stipulate a penalty for this crime.

\subsubsection{The Intervention of the Authority Personnel in the Electoral Publicity Crime}

Under the electoral law of the House of Representatives, the members of the public authority must be fully adhered to neutrality towards the candidates. Article 23 of the law prohibits the government employees, official and public institutions, the secretary of Amman, the Board members, their employees, heads of provincial, municipal and local councils, their members and staff from carrying out any advertising and campaigning activity for any candidate in their place of work. It also prohibited the use of any means and assets owned by these institutions in the electoral campaigning of any candidate. Article (8) of the executive regulations concerning the rules of the electoral campaigning of 2016 also prohibits the high-level officials in public official institutions from intervening or exploiting their positions in the favor of any candidate or list. In the intervention of the authority personnel in the electoral publicity crime, the perpetrator must be an employee of the public authority or the local authority then he uses his powers and influence, or the property of the state or its funds in the electoral publicity in favor of one of the candidates. The material element of this crime is the criminal behavior that is contrary to the principle of neutrality, which is any interference in the favor of any candidate or against it, regardless of where it is exercised. Article 23 stipulates that members of the public or local authority shall not exercise the activities of electoral publicity in their places of work. This is in contrast to most of the electoral legislations that prohibited the employees from carrying out electoral publicity inside and outside their workplace. This is what the French legislator has adopted in Article 50 of the French Election Law. The intervention of the authority personnel in the electoral publicity is a deliberate crime, in which the moral element

\footnotetext{
${ }_{19}$ Al-Zubaidi, Muhannad, ( 2018), Criminal liability of the Moral Person for Electoral Crimes, PhD, University of Alexandria, p. 32 and beyond.

${ }^{20}$ EL-Asadi, op. Cit., P. 306.

${ }^{21}$ EL-Asadi, op. Cit., P. 298.

${ }^{22}$ Anyone who commits this offense shall be punished under the provisions of Article (61) of the Election Law, which provides for imprisonment for a period of not less than one month and not more than six months or a fine not less than one hundred dinars and not more than three hundred dinars or by both penalties for every violation of the provisions of the electoral law of the House of Representatives that does not have a prescribed penalty.
} 
is realized by the existence of the criminal intent with its elements (the knowledge and the will). The perpetrator should be aware of the elements of the criminal conduct which are based on the violation of the principle of neutrality by intervening in the electoral publicity in favor of a candidate by any mean, and his will should aim at achieving that result voluntarily and consciously. The Jordanian legislator punished this crime by imprisonment for a period of not less than three months and not more than one year or a fine not less than two hundred dinars and not more than five hundred dinars or by both penalties. According to article 56 of the Jordanian House of Representatives Electoral Law No. 6 of $2016^{23}$, the crime can be committed by a public moral person, when the media institutions that are affiliated with the Ministry of Information such as the state television or an official newspaper affiliated with a Ministry promotes a specific candidates in the elections, although it cannot be held accountable as it is a public moral person.

\subsection{Crimes That Are Related to the Subject of the Electoral Publicity}

The electoral publicity is based on persuading voters and influencing them. The legitimacy of the electoral publicity requires the criminalization of the acts that affect the conduct of the electoral process and its results. Therefore, the Jordanian legislator prohibited in Article 22 (A/4) of the Electoral Law of the House of Representatives the speeches, statements, advertisements and means of electoral publicity from directly or indirectly offending any candidate or any other person or incite any religious, sectarian, tribal or regional strife among citizens because these acts tricks the voters. The crime of publishing and broadcasting false statements related to the subject of the election or the conduct of one of the candidates and the crime of violating the subject of the electoral publicity are the most important crimes. Acts of publishing or broadcasting false news must be committed after the issuance of the decision of inviting the voters to the election until the completion of this election, i.e. throughout the electoral process. But if the acts of publishing or broadcasting false news are committed outside the time frame of the electoral process, they will be outside the scope of criminalization. According to the electoral legislation, they are not considered electoral crimes. However, the criminalization provisions included in the Jordanian Penal Code can be applied as these acts which constitute this crime may be from the crimes of libel, slander and denigration ${ }^{24}$.

This crime can also be committed by a moral person. The material element of this crime is represented in publishing or broadcasting false statements regarding the subject of the elections, the behavior or morals of a candidate or to kindle prejudicial rumors or inciting religious, sectarian, regional, tribal strife or threats the unity of the country and its independence among citizens by any media affiliated to or working for a political party. The moral element of this crime requires the existence of the general intention that requires knowledge and will i.e., the moral person is aware of the acts that constitutes the material element of this crime, and despite this, he commits the crime.

\subsection{The Crime of Illegitimate Financing and Spending on the Electoral Publicity}

The Jordanian legislator prohibited any candidate or list from accepting any donations or material or financial contributions from foreign countries and governments, official and civil international organizations, foreign companies and foreign nationals whether in cash or in kind as well as accepting any money that the candidate know that they were collected from illegal sources, or the money of wanted persons, or illegal institutions ${ }^{25}$.The Jordanian legislator organized the expenses and the funding of the electoral publicity within the executive instructions related to the campaigning rules of 2016, where he set the ceiling for spending on the electoral publicity and the sources of spending on the electoral publicity ${ }^{26}$. Article (15) of the same instructions requires each list to open a bank account for the purposes of resources and use of fund on the campaign, in which the amounts are allocated to the campaign. Paragraph (b) of the same Article also obligates the lists and the candidates to appoint a legal auditor who will audit the accounts of the list. The bank account shall not be closed until the commissioner of the list submits an affidavit confirming that the list is discharged from any third party entitlement. Article (16) of the same instructions obliges the lists that are running in more than one electoral district to keep numbered records that are sealed by the Independent Electoral Commission.

The crime of illegitimate financing and spending on the electoral publicity can be committed by a moral person such as a political party. The criminal behavior that constitutes the material element of this crime can be

\footnotetext{
${ }^{23}$ Paragraph (c) of Article 56 of the Jordanian Electoral Law provides for this penalty for all the prohibited acts, including Article (23), which prohibits the authority personnel from interfering in the electoral publicity.

${ }^{24}$ Article (188) Of the Jordanian Penal Code No. (16) Of 1960 and its amendments

${ }_{25}$ Article 13 of the executive regulations that is related to the rules of the campaigning of 2016.

${ }^{26}$ Article 14 of the executive regulations that is related to the rules of the campaigning of 2016.
} 
represented in one of these forms: Positive behavior, which is represented by the political party financing its electoral campaign from prohibited parties that the law does not allow the receipt of funding from them, such as foreign persons, whether natural or legal, or accept amounts that are greater than the amounts allocated to finance the campaign from the legitimate sources specified by the law, for example, a political party accepted a donation that exceeds the maximum limit prescribed by the law. The second form of the positive behavior is represented in spending amounts that exceeds the maximum limit prescribed by the law on the electoral publicity, regardless of the value of the over expenditure. The third form is a negative behavior: the political party's failure to open a bank account or to submit the electoral campaign records to the independent electoral authority, or to provide incorrect information about the amounts deposited or disbursed. The material element of this crime is also based on a negative act: The financial agent of the party or the electoral list that represents a political party intentionally ignores the rules governing the financing of electoral campaigns or the maximum amount of donations. The moral element of this crime is represented in the existence of general criminal intent i.e. the person is aware of the fact that the funds came from prohibited parties, or that the expenditure exceeds the legal limit, or the failure to open a bank account for the electoral campaign and not depositing the funding and the donations in it. However, he commits the acts willingly. The legislator did not provide for a specific penalty for this crime, so the penalty that is contained in article 61 of the Penal Code shall apply. We hope that the Jordanian legislator will provide a penalty for this crime within the electoral law.

\subsection{The Crimes of Influencing the Will of the Voters}

\subsubsection{The Electoral Bribery}

Article 24 of the Electoral Law stipulates that: "It is prohibited for any candidate to offer during the electoral publicity gifts, donations, cash or in-kind benefits or other advantages, or to promise to offer it to a natural or moral person, directly or indirectly. It is also prohibited for any person to request such gifts, donations, benefits or the promise of it from any candidate". The crime of electoral bribery is one of the most serious electoral crimes, because of the ease of resorting to it by some candidates or lists that represents political parties. The Jordanian legislator has criminalized the electoral bribery in Article 59 of the Electoral Law of the House of Representatives No. 6 of 2016, which stipulates the following: shall be punished by hand labor for a period of not less than three years and not more than seven years anyone who: (a) directly or indirectly gives, lends, offers or pledges a sum of money, interest or any other remuneration in order to induce the voters to vote in particular or abstain from voting or to influence others to vote or abstain from voting (B) Directly or indirectly accepts an amount of money, a loan, a benefit or any other remuneration for himself or for another person with a intention to make him vote particularly or abstain from voting or to influence others to vote or abstain from voting "., From the extrapolation of the text of Article 59, we can determine the elements of the crime of electoral bribery: a presumed element (the bribe-taker), and a material and moral element.

The moral person can commit the crime of electoral bribery that assumes the existence of the briber, the bribe-taker, the mediator. The briber can be a natural or a moral person. This is due to the generality of the text of article (59) "anyone who directly or indirectly gives". The briber can be the political party, where he bribes the voters to vote for the candidate of the party or the list of the party. In contrast, the party may be one of the enemies of another party, which bribe the voters to abstain from voting for the party or its list. The bribe-taker in the electoral bribery is the one who accepted or asked directly or indirectly for a sum of money, a loan, a benefit or any other enumeration. The existence of the status of the voter is required. The mediator may be a moral person that represents the link between the briber and the bribe-taker. Article (59) did not require any special status as the words of the text where general by using the term " "anyone" who gives ". The mediator may belong to a political party, association or other. The material element of the electoral bribery crime consists of three elements: criminal behavior, criminal result and causal relationship between them. The Jordanian legislator determined the acts that constitute the material element of the crime of electoral bribery in Article (59) of the Electoral Law No. 6 of 2016. In paragraph (1) of Article (59), the Jordanian legislator stipulated the material behavior of the electoral bribery crime committed by the briber, which is the presentation of the bribe. Its forms are to give directly or indirectly, the loan or the promise of interest. In paragraph (2) of Article (59), the Jordanian legislator provided for the material behavior of the electoral bribery crime committed by the voter, which according to the text is the acceptance, demand directly or indirectly and taking. All of these forms apply one subject, which is the benefit (the subject of the electoral crime). The Jordanian legislator has expanded the definition of the electoral bribery, using loose terms for the benefit without elaboration. According to Article 59/ A, it is a sum of money or interest or any other consideration. The text did not limit it to certain forms. According to this concept, cash, donations, cash and in kind gifts, promises of gifts, benefits, public or private jobs are considered a benefit or an interest. The criminal result of the crime of electoral bribery is represented in 
influencing the will of the voters to vote in a particular manner, or abstain from voting in accordance with the interest of bribers. A causal relationship must exist between the conduct and the result. Since the crime of electoral bribery is a harm offence that requires a result, the causal link between the conduct and the result must exist ${ }^{27}$. The moral element of the crime of electoral bribery takes the form of general criminal intention that is based on knowledge and will. According to Article 59 of the Electoral Law No.6 of $2016^{28}$, the special intention must exists which is to influence the voters to vote in favor of a particular candidate or to abstain from voting. The Jordanian legislator punishes the perpetrator of the crime of electoral bribery by a custodial penalty which is hard labor for a period not less than three years and not more than seven years.

\section{Criminal Confrontation of Electoral Crimes Committed by the Moral Person in the Electoral Law of the House of Representatives of 2016}

The Jordanian legislator has recognized the penal liability of the moral person for all crimes in Article 74 of the Penal Code ${ }^{29}$ by adopting the theory of reality that considers the moral person to be a real entity not a fiction. The public moral persons are excluded from this responsibility, which are the governmental department, official or public institution. In the text of article 36, public administrations are excluded from the penalty of suspension. According to article 74, the penal liability of the public moral person, such as the state or any ministry or its official institutions or bodies, is not responsible for the crimes of electoral publicity, but it is possible for the natural person who has already served as minister, chairman or director of an official institution to be held accountable. The penal liability of the moral person for the crimes of electoral publicity is limited to the private moral persons not the public persons.

The question arises as to the nature and scope of the penal liability of the moral person. The liability of the moral person can be direct or indirect.

- Direct Penal Liability: In direct penal liability, the moral person bears alone the full criminal responsibility resulting from the conduct that was made in his name, regardless of the liability of the natural person who manages or represents it. This was adopted by the Jordanian criminal legislator in article $74 / 2^{30}$ of the Penal Code. Such recognition of the direct penal liability of the moral person is contained in Article 36, which deals with precautionary measures that can be taken against the perpetrator. It stated: "Every union and every company can be suspended." The same approach in terms of the direct penal liability of the moral person is contained in the provisions of Article 37 of the Penal Code. Thus, we see that the Jordanian criminal legislator has adopted the direct penal liability of the moral person as long as the acts were committed in his personal name. The Jordanian Court of Cassation upheld the direct penal liability of the moral person ${ }^{31}$.

- Indirect Penal Liability: This liability exists when the law provides for a joint liability between the moral person and the natural person during implementing the sanction. According to the literal text of article 74/2 of the Penal Code, the liability of the moral person is considered a direct liability as the natural person cannot be held accountable as the president, members of his administration, directorate, representatives or employees as long as the act is committed on his behalf or for his account. The Jordanian legislator did not depart from this rule except in Article 442 of the Jordanian Penal Code that states the following: If the crime is committed in the name of a company or for its own account, this company shall be targeted for the application of the precautionary measures. The penalties provided for in the preceding article targets the person who is in charge of the company and has contributed in the act or facilitated or allowed its occurrence intentionally". The court of cassation has settled in many of its decisions issued by the General department that punishing a company according to article 74 does not mean that the perpetrator should not be punished even if he committed it in the

\footnotetext{
${ }^{27}$ El -Asadi, op. Cit., P. 401.

${ }^{28}$ Where paragraph (a) stated that: ..... in order to induce him to vote in particular.

29 Article $74 / 2$ of the Jordanian Penal Code

${ }^{30}$ Article 74 of the Jordanian Penal Code.

${ }^{31}$ Judgment of the court of cassation No. 38/1973 states that article 74 of the Penal Code of 1960 stipulates that moral bodies are responsible for the acts of their directors and representatives when such acts come in their name or by one of its means as a moral person. This is the general rule. The Court considers that the Penal Code has exempted the crime laid down in Article 441 of the Jordanian Penal Code. Article 442 requires the punishment of the moral person and the punishment of those who contributed to or intentionally commited the act. (a judgment of the court of cassation, the Journal of the Bar Association, 1973, p. 1987). The same provision states that: "... if the complainant issues a check in the name of the company he represents and not in his personal name, he may not be punished for this act, but the company itself is responsible under article 74. If the law wanted to consider the person issuing the check in such a case liable, he would have provided an exceptional text for that. "
} 
name of the moral person ${ }^{32}$. Different rulings have been issued by the Jordanian Court of Cassation. It sometimes adopts the direct liability of the moral person, where the moral person alone bears the full criminal liability if he committed the act in his name or by one of his means as a moral person. At other times it adopts the indirect responsibility, where the Jordanian legislator recognized the penal responsibility of the moral person on the basis of personal and direct responsibility which is based on the theory of reality. We hope that the Jordanian legislator will amend the text of article $74 / 2$ and add the phrase: "without prejudice to the liability of his representative who committed this crime".

\subsection{The Conditions of the Penal Liability of the Moral Person in the Electoral Crimes}

The penal liability of the moral person differs in relation to the rules of attribution of the penal liability of the natural person as it is a conditional responsibility in which several conditions must be met. According to article $74 / 2$ of the Penal Code, the penal liability of a moral person in the electoral publicity crimes requires the following conditions:

1) The perpetration of one of the electoral publicity crimes stipulated in the electoral legislations.

The Jordanian legislator adopted the principle of generality in article $74 / 2$ of the Penal Code, and did not specify the crimes for which the person may be held accountable. Therefore, the moral person can be liable for all the electoral publicity crimes that is provided for in the electoral law of the House of Representatives No. 6 of 2016, or in the executive instructions concerning the rules of electoral campaigning ${ }^{33}$.

2) The perpetration of one of the electoral publicity crimes through a member of the moral person or its representatives.

This condition requires that the perpetration of the electoral crime through one of the natural persons who represent the moral person or administer it or work for it and have the right to express its will. They are his brain and his working hand ${ }^{34}$. The legislation differed in determining the natural persons that the moral person can be held accountable for their criminal behavior. Some of them limited it to the actions of the members and representatives of the moral person such as the French law ${ }^{35}$, while other legislation expanded and decided the liability of all its employees, staff and subordinates. The Jordanian legislator adopted this approach, where he extended the penal liability of the moral person to include every person that is under his umbrella regardless of their occupational authority. The moral person becomes liable, in the sense of article 74/2 of the Penal Code, when the act is committed by the head of the moral person or by a member of its board, directors or any representative or employee thereof. The Jordanian legislator confirmed the adoption of this trend in Article 36 of the Penal Code ${ }^{36}$, where he stressed the same categories that commit crimes in the name of the moral person in respect of the penalty of suspension that is imposed on the moral person. We believe that this is a good Position for the Jordanian legislator because the moral persons, such as political parties, associations, trade unions, newspapers, satellite channels and campaigning companies, carry out acts that affect the integrity of the electoral process. The director of the moral person, his representative, his agent, his staff and his employees may be identified through the records of the moral person.

3) The perpetration of the electoral publicity crimes for the account of the moral person.

The electoral crime must be committed in order to achieve the interest or the profit of the moral person, or to avoid a loss or damage, whether the interest is material or intangible, direct or indirect, achieved or possible. According to the text, the moral person shall not be held accountable for the electoral crimes committed by one of his members or representatives or one of his employees for his personal account or to achieve personal

\footnotetext{
${ }^{32}$ In this respect, the Jordanian Court of Cassation ruled that: "The directors of the moral person and the members of its administration are not exempted from the penal liability when they commit punishable acts on behalf of the said bodies or by one of their means. They are considered liable as independent perpetrators as long as the perpetrated the act willingly as well as the responsibility of the company they represent because when legislator provided for the punishment of the moral person, he did not intend to remove the original actors from the scope of responsibility (Judgment of the court of cassation No. 31/1973, Judgment of the court of cassation No. 69/1973)

${ }_{33}$ Instructions No. 7 of 2016, the executive instructions for the rules of election campaigning issued under Article 20, paragraph B of the Electoral Law of the House of Representatives No.6 of 2016.

${ }^{34}$ ALShashani, op. Cit., P. 195.

${ }_{35}$ Article 121-2 of the French Penal Code limited the penal liability of a moral person to his members and representatives only without his subordinates or his employees.

36 "Any union, company or association and any moral person, except public administrations, may be suspended if its managers, members of its administration, representatives or employees had committed an intentional felony or misdemeanor, punishable by at least two years of imprisonment, in its name or by one of its means.
} 
interest or the interest of another person or to harm the moral person ${ }^{37}$.This coincides with the requirements of justice and the significance of the text. The Jordanian legislator extended the scope of the penal liability of the moral person by requiring the perpetration of the crime in the name of the moral person or by any of its means if it is committed by the members of the administration, directors, representatives or employees, unlike the French legislator who required two conditions only for the penal liability of the moral person. : The first is the perpetration of the crime for the account of the moral person only, without requiring its perpetration in the name of the moral person or by one of its means; The second: the perpetration of the crime by his members and representatives only, without his other employees which narrows the scope of the liability of the moral person.

\subsection{The Penalties provided for the Moral Person}

If a moral person commits any of the crimes of the electoral publicity, he may be held accountable according to the provisions of Article 74 of the Jordanian Penal Code. According to article 74/3 of the Jordanian Penal Code 38 , the penalties that can be imposed on a moral person are fine and confiscation.

\subsubsection{The Fine}

The fine is one of the most important penalties that affect the patrimony of the moral person. It is also one of the most important penalties that are imposed on the moral person. The fine is an original penalty, unlike confiscation, which cannot be considered an original penalty. It is either an additional penalty or a precautionary measure. Under article $74 / 3^{39}$, if the law provides for an original penalty other than fine, it shall be substituted by a fine within the limits specified in articles 22 to 24 of the Penal Code ${ }^{40}$.

Therefore, if a private moral person, such as political parties, campaigning companies, audio-visual private media, the press, any association, civil society organizations, commits any electoral publicity crime, he shall be held accountable according to Article 74 of the Jordanian Penal Code. If the penalty prescribed for the committed crime is not suitable to be applied to the moral person such as the deprivation of liberty, it shall be replaced by an appropriate penalty, i.e. the fine. We see that article 74/3 of the Jordanian Penal Code had not specified the maximum limit of fine that can be imposed on private moral persons in case of committing an electoral crime. He gave the judge the discretion to impose it if it is impossible to apply the sentence to the moral person within the limits of article 22 of the Penal Code. According to this article, the fine ranges from five dinar to two hundred dinar, unless otherwise provided by law. In this case, the judge must abide by the fine stipulated in the text because it is limited to a maximum limit. The electoral law No. 6 of 2016 did not include any special provision regarding the amount of the fine imposed on the moral person in the case of committing an electoral crime. In this case the judge must abide by the fine stipulated in the text because it is limited to a maximum limit. Thus the maximum limit of the penalty that can be imposed on the moral person in case of committing an electoral crime is two hundred dinars. This means that the Jordanian legislator did not take into account the difference between the natural person and the moral person. In our view, the penalty should be aggravated when it is a fine in addition to what is imposed on the natural person who represents the moral person or acting in his name or by his means, unlike the French legislator who imposed a fine that is five times the fine imposed on the natural person ${ }^{41}$. The Jordanian legislator has expressly stated the amount of fine imposed on a moral person in other laws, for example the Human Trafficking Act No. 9 of 2009, in which article 11 / A stipulates that: (The moral person shall be punished by a fine not less than ten thousand dinar and not more than fifty thousand dinar if he commits any of the crimes stipulated in this law without prejudice to the liability of his representative who perpetrated this crime).

This penalty raises a lot of problems in its execution in the event of the failure of the moral person to pay the fine voluntarily because it is impossible to force the moral person to pay the fine as a penalty or to fulfill it through the period of imprisonment stipulated in Article 22 of the Jordanian Penal Code, which stipulates the imprisonment for one day for every ten dinar or its fractions, provided that the period of imprisonment does not exceed one year. The Jordanian Criminal Procedure Code did not contain any provision that enable the Public

\footnotetext{
${ }^{37}$ Kamel , 1997, op. Cit,P. 130.

${ }^{38}$ Which states: "Moral persons shall only be sentenced to fine and confiscation."

${ }^{39}$ Which stipulates that: "... If the law provides for an original penalty other than the fine, it shall be replaced by the fine and shall be imposed on the moral persons within the limits specified in Articles 22 to 24 of this Law"

${ }^{40}$ Articles 22-24 of the Jordanian Penal Code stipulate the following: Article 22: "The fine: is to oblige the convicted person to pay the amount estimated in the judgment to the government treasury, which ranges from five dinar to two hundred dinar, unless otherwise stipulated by the law."

${ }^{41}$ Article 131-38 Act no. 2004-204 of 9 March 2004. Article 55, Official Journal of 10 March 2004.
} 
Prosecution to enforce the fine on a moral person in such a case ${ }^{42}$.

\subsubsection{Confiscation}

The confiscation: is to forcibly transfer the ownership of the objects that is related to the crime from its owner to the public authorities. Confiscation is not an original penalty, but it is either an additional penalty or a precautionary measure. It can be imposed as an additional penalty to the penalty of the felony or the misdemeanor such as the confiscation stipulated in Article 44/2 of the Jordanian Penal Code. It may be a precautionary measure, such as the confiscation prescribed in Article 31 of the Jordanian Penal Code. In this case, it is a mandatory penalty which the court must impose. According to the Code of Criminal Procedure, the penalty of confiscation is carried out on the seized items by confiscation them directly because they are in the possession of the Public Prosecution. But if the objects designated for confiscation are not seized, the Jordanian legislator does not provide texts that show how the confiscation should be implemented in such case, which could be considered a legislative deficiency.

\subsection{Precautionary Measures}

The Jordanian legislator provided in Articles 35-37 the precautionary measures that can be imposed on the moral person, namely, the closure of the premises, suspension from work, or the dissolution of the moral person.

\subsubsection{The Closure of the Premises}

According to Article 35/1, the court may close the premises where a crime was committed by the act of its owner or to his satisfaction for a period not less than one month and not more than one year.

\subsubsection{Suspension from Work}

The Jordanian legislator provided for this measure in Article 36 of the Penal Code. According to this provision, two conditions are required: The perpetration of the crime by the moral person, his employees or his representatives in his name or by any of his means; the committed crime must be an intentional felony or misdemeanor that carries a penalty of not less than two years imprisonment. In this regard, we see that this narrows the scope of the penal liability of the moral person. According to the article laid down by Jordanian legislator, the moral person shall not be suspended from work if the crime was an unintentional misdemeanor or an intentional misdemeanor that carries a penalty that is less than two years imprisonment or an infraction. The legislator also determined the period of the suspension, which is not less than one month and not more than one year ${ }^{43}$.

\subsubsection{The Dissolution of the Moral Person}

The Jordanian legislator stipulated this measure in Article 28 of the Penal Code and determined the cases of dissolving the moral person in Article 37 of the Penal Code, which are: (A) if it has not complied with the legal requirements for its establishment. (B) If the purpose for which it was established is contrary to the law, or as a practical matter it pursues such purposes. (C) If it contravenes provisions of the law where the violation of which expressly entails dissolution. (D) If it has previously been closed down by an official decree within the previous five years. According to article 38/2, this precautionary measure shall result in the liquidation of the moral person's money, and the directors or members of the administration and any person responsible for civil crime shall lose the capacity to establish a similar body or to administer it.

The Jordanian legislator did not stipulate in the Criminal Procedure Law, which is considered the law that regulates the implementation of the Criminal sentences, the mechanism of implementing the dissolution of the moral person or his suspension from work. The Penal Code did not specify the procedures for their execution, but only criminalized the violation of their provisions. The Jordanian legislator did not provide for the penalty of publishing the sentence of the moral person in the written press or the use of any form of communication with the public through electronic means, unlike the French legislator ${ }^{44}$. The Jordanian legislator did not also provide for the penalty of putting the moral person under judicial supervision, which the French legislator imposed on the moral person ${ }^{45}$. The penalty of judicial supervision in the French law does not apply to public moral persons, whose actions are delegable, and political parties and groups.

\footnotetext{
${ }^{42}$ ALShalabi , Zaid Nidal\& Obaid ,Emad Mahmoud, (2016), The Problems of Implementing the Criminal sentence against the Moral Person: Comparative Study in Jordanian and Egyptian Law, Dirasat Journal, Shariah and Law Studies, Volume 43, No. 2, 2016, P 810-812.

${ }^{43}$ ALShashani,op.cit, p.204

${ }^{44}$ Article 131-39-9 " posting a public notice of the decision or disseminating the decision in the written press or using any form of communication to the public by electronic means.

${ }^{45}$ Article 131-39-3:" placement under judicial supervision for a maximum period of five years".
} 
Moreover, the Jordanian legislator did not provide for the penalty of prohibition stipulated in article 12/39/131 of the French Penal Code by preventing the moral person from benefiting from the receipt of public assistance granted by the State, or from any assistance provided by a private person. In this regard, we see that the Jordanian legislator should adopt modern sanctions that are in line with the modern legislative policy in the electoral law of the House of Representatives to achieve the functions of public and private deterrence in the electoral crimes.

\section{Conclusion}

After clarifying the provisions of the penal liability of the moral person for the crimes of electoral publicity in the Jordanian House of Representatives Electoral Law No. 6 of 2016 and clarifying the problems of the implementation of criminal sentences and the issues of its application, we put the following suggestions in order to ensure the expansion of the criminal protection of the will of voters on the one hand, and that the perpetrators did not enjoy impunity on the other hand:

1) According to the principle of legality of procedures, and taking into account the nature of the moral person, we hope that the Jordanian legislator will adopt an integrated procedural system to prosecute the moral person.

2) The Jordanian legislator should adopt modern sanctions that commensurate with the nature of the moral person and that are in line with the modern legislative policy in the electoral law of the House of Representatives to achieve the functions of public and private deterrence in electoral crimes, for example a high monetary fine, publishing the sentence, placement under judicial supervision, deprivation of rights and benefits.

3) We hope that the Jordanian legislator will amend the electoral law of the House of Representatives No. 6 of 2016 and explicitly stipulate the indirect liability of the moral person so as not to exclude the liability of the natural person, which is the representative of the moral person, if the crime was committed in the name of the legal person or by one of his means.

\section{References}

Al Outour, R. I. (2006). The Penal Liability of the moral Person. Damascus University Journal of Economic and Legal Sciences, 22(2).

Al-Hadithi, O. F. A. R. (2010). The Prevention of the Electoral Crime. Research published in the Journal of the Faculty of Law, Anbar University.

ALShalabi, Z. N., \& Obaid, E. M. (2016). The Problems of Implementing the Criminal sentence against the Moral Person: Comparative Study in Jordanian and Egyptian Law. Dirasat Journal, Shariah and Law Studies, 43(2).

ALShashani, R. (2014). The Criminal Liability of the moral Person in Accordance with the Jordanian Legislator's Plan. Al-Manara Journal, 20(2).

Al-Zoubi, M. (2012). The Impact of the Penal Liability of the Moral Person on the Protection of Public Money Comparative Study. PhD, Amman Arab University.

Al-Zubaidi, M. (2018). Criminal liability of the Moral Person for Electoral Crimes. PhD, University of Alexandria.

EL -Wardi, B. (2008). The Legal System of Electoral Crimes (1st ed.). Alexandria University, Thought House.

El-Asadi, D. A. A. (2009). Electoral Crimes (1st ed.). Zain Legal Library, Lebanon.

Kamel, S. S. (1997). The Penal Liability of the Moral Persons - Comparative Study (1st ed.). Dar Al-Nahda al-Arabiya.

Muqbel, A. M. Q. (2005). Criminal Liability of the Moral Person (Issue 1). Cairo University: Egypt.

Saleh, I. A. (1980). The Criminal Liability of Moral Persons. Cairo, Dar Al Maarif.

\section{Copyrights}

Copyright for this article is retained by the author(s), with first publication rights granted to the journal.

This is an open-access article distributed under the terms and conditions of the Creative Commons Attribution license (http://creativecommons.org/licenses/by/4.0/). 